Review Article

\title{
Systematic Review: Contraceptive Knowledge and Use in Saudi Arabia
}

\author{
Rana Ahmed Bamufleh, Ahlam Eidah Al-Zahrani, Shadia Abdullah Yousuf \\ Faculty of Nursing, King Abdulaziz University, Jeddah, Saudi Arabia \\ Email address: \\ Ranoosweet2006@hotmail.com (R. A. Bamufleh)
}

\section{To cite this article:}

Rana Ahmed Bamufleh, Ahlam Eidah Al-Zahrani, Shadia Abdullah Yousuf. Systematic Review: Contraceptive Knowledge and Use in Saudi Arabia. Journal of Gynecology and Obstetrics. Vol. 5, No. 6, 2017, pp. 69-77. doi: 10.11648/j.jgo.20170506.11

Received: October 3, 2017; Accepted: October 3,, 2017; Published: November 23, 2017

\begin{abstract}
Introduction: Contraceptive use was remaining as paramount importance to women's health. In the kingdom of Saudi Arabia (KSA), it was found that up to $62.8 \%$ of fertile married Saudi women do not use contraceptive methods. While, the women who are using contraceptive methods, they do not have adequate knowledge. The purpose of the systematic review in the current study is to retrieve all researches that related to contraceptive method in KSA. Methods: two questions were used to guide the review were: (1) What are the women's knowledge and use of contraceptive methods in SA, (2) Does the contraceptive counseling conducted in KSA? Five electronic databases were used to find studies. The search started from 26 th of April 2015 until 5th of May 2015. Then, it was repeated in the first of April 2017 until May 2017. Certain criteria were used to minimize the studies which were; full text article, included the married women from 18-49 years, English articles and within 2000 to 2017 years. Result: twenty-one of studies were found and met the search criteria in this review. Several Saudi studies have reported that most women have heard contraceptives but still had inadequate knowledge about benefits and side effects. The studies reported that the main sources of women's contraceptive knowledge $(53.7 \%)$ were friends and family members. Two studies found that nurses have very limited roles in contraceptive and family planning education. It is disappointing that none of the women mentioned receiving contraceptive education or information by nurses. Fifteen studies have conclude that women had used contraceptives. The most commonly used contraceptive in SA is the oral pill, IUDs and fertility awareness. Other contraceptive methods such as lactational amenorrhea, withdrawal, injections, spermicidal and tubal ligation are also noted to be used by women. all of the studies agreed that effective counseling and education were needed to improve women's knowledge and enable them to use their preferred contraceptive method properly Conclusion: nurses have very limited roles in contraceptive and family planning education.
\end{abstract}

Keywords: Contraceptive, Family Planning, Birth Control, Contraceptive Use

\section{Introduction}

Contraceptive use was remaining as paramount importance to women's health [1]. The United Nation (2015) reported that $64 \%$ of married women used some of contraceptive methods. However, contraceptive use was much lower $40 \%$ in the least developed countries [2]. According to the General Authority for Statistics (GASTAT) in the kingdom of Saudi Arabia (KSA), found that up to $62.8 \%$ of fertile married Saudi women do not use contraceptive methods [3]. While, the women who are using contraceptive methods, they do not have adequate knowledge $[4,5,6,7]$.
The purpose of the systematic review in the current study is to retrieve all researches that related to contraceptive method in KSA.

\section{Method}

The search questions that used to guide the review were: (1) What are the women's knowledge and use of contraceptive methods in SA, (2) Does the contraceptive counseling conducted in KSA? Five electronic databases that used to find studies that can answer the search questions. These databases were Cumulative index to Nursing and Allied Health 
Literature (CINAHL), EBSCO, Pub Med, PMC, Since Direct and Google Scholar. All studies that found in databases were summarized in (Table 1).

Table 1. Databases used and studies found in search.

\begin{tabular}{ll}
\hline Database & Related Articles \\
\hline CINAHL with EBSCO & 1 \\
Since Direct & 1 \\
Pub Med & 3 \\
Google Scholar & 12 \\
PMC & 1 \\
Hand search $\backslash$ Saudi Medical Journal & 3 \\
Total & 21 \\
\hline
\end{tabular}

The keywords used to identify the studies were contraceptives, contraception, Contraceptive counseling, Contraceptive use and a lot of other word that identified in (Table 2).

Table 2. Keywords used in search.

\begin{tabular}{lll}
\hline keywords used in search & & \\
\hline Contraceptives & Contraceptive counseling & Birth control \\
Contraception & Contraceptive use /practice & Child space \\
Contraceptive Knowledge & Family planning & Birth control \\
Contraceptive Education & Birth interval & Child space \\
\hline
\end{tabular}

The keywords were used separately or together in all databases and combined with the ward of KSA. The search started from 26th of April 2015 until $5^{\text {th }}$ of May 2015. Then, it was repeated in the first of April 2017 until May 2017. It was used certain criteria to minimize the studies that related to the search questions which were; full text article, included the married women from 18-49 years, English articles and within 2000 to 2017 years. Moreover, the word Saudi Arabia was used in all search words. Furthermore, the researcher reviewed the references of the article that obtained from the databases to ensure that all relevant studies not missed. The researcher found a lot of articles in the Google Scholar that related to search questions and they were full text and easy to access rather than other databases searched. Totally, twenty-one of studies were found and met the search criteria that summarized in table 6 . The researcher found seven studies covered all type of contraceptive methods $[4,6,8,9,10,11,12]$. Also, eleven studies focused on one or two types of contraceptives that were commonly used in SA $[6,13,14,15,16,17,18,19$, 20, 21, 22].

\section{Result}

\subsection{Knowledge About Contraceptive Methods}

Twelve studies were found that assessed women's knowledge about contraceptive methods $[4,6,8,11,12,15,16$, $18,20,22,23,24]$. Knowledge of contraceptive methods is summarized in (Table 3). Hassan's study that conducted in SA found that mothers knew about contraceptive methods but still had poor knowledge about methods' benefits and side effects [25]. The studies by Al-Zahrani, Al Sheeha, and Al-Mansour, Sabra, and Hafez agreed that the women had limited knowledge about contraceptives [4, 6, 8]. Similarly, a study by Elgharabawy, Ahmed, and Alsuhaibani reported that $18 \%$ of women had no idea about contraceptives [11].

Several studies focused exclusively on oral contraceptive methods and found that women had inadequate knowledge. They concluded that Saudi women need effective counseling to enhance their knowledge $[4,6,16,18,22]$. In contrast, one study found women had high levels of knowledge about oral contraceptive. However, this study recommended that awareness regarding contraceptives should be increased to overcome women's misconceptions about oral contraceptives [20].

IUDs were the second most recognised contraceptive in SA; studies reported that $67 \%$ and $88.5 \%$ of women knew about IUD $[4,12]$. Furthermore, the male condom was known by $46.8 \%$ and $61 \%$, respectively [4, 12]. Farih's study found that $43 \%$ of woman knew about the diaphragm. Although both studies was conducted in Riyadh which is highly conservative region, it showed that women know about forms of contraception like condoms and the diaphragm.

Al-Turki's study explored permanent contraceptives and found that $29.8 \%$ of respondents had no knowledge about permanent methods of contraception [15]. Similarly, Farih's study noted that few women knew about fallopian ligation (15.6\%) and male sterilization (11.2\%) [12].

Sobande et al.'s study endeavoured to determine the efficacy of injections for women who had already used injections of Depo-Provera [23]. That study found that although $80 \%$ of women knew about Depo-Provera injections, only $30 \%$ had heard about its possible side effects. Similarly, other study found that $74 \%$ knew about contraceptive injections [12].

In a study of Karim and his colleagues found the majority of women (93.8\%) have not knowledge of EC and they are only (6.2\%) stated that EC can be done after unprotected sex to prevent pregnancy. Moreover, none of the participated women know about insertion of an IUD as a method for EC [24].

Table 3. Knowledge of contraceptive methods.

\begin{tabular}{llll}
\hline Contraceptives knowledge & Studies & Sobande et al. 2000 & Al Sheeha 2010 \\
\hline Oral pill & - & $9 \%$ have Excelent Knowledge \\
IUD & - & $69 \%$ & - \\
Injection & $80 \%$ & - & - \\
Condom & - & $46.8 \%$ & - \\
Diaphragm & - & $9.7 \%$ & - \\
Permanent methods & - & - & $29.8 \%$ \\
\hline
\end{tabular}




\begin{tabular}{|c|c|c|c|c|}
\hline Contraceptives knowledge & Al-Mansour Sabra \& Hafez 2012 & Al-Shaikh et al. 2012 & Iftikhar, Aba Al Khail, 2015 & Farih 2016 \\
\hline Oral pill & $36.3 \%$ had knowledge & $\begin{array}{l}9.8 \% \text { in case of vomit } \\
79.3 \% \text { in case of missed pill }\end{array}$ & $\begin{array}{l}20 \% \text { in case of vomit } \\
64.5 \% \text { in case of missed pill }\end{array}$ & $94.2 \%$ \\
\hline IUD & - & - & - & $88.5 \%$ \\
\hline Injection & - & - & - & $74.2 \%$ \\
\hline Condom & - & - & - & $61 \%$ \\
\hline Diaphragm & - & - & - & $43 \%$ \\
\hline
\end{tabular}

\subsection{Source of Information}

Eight studies investigated women's sources of information about contraceptive methods $[4,8,12,13,15,18,20,24]$. Family members were most commonly mentioned as sources of knowledge about contraceptive methods; they were cited by $32.9 \%, 67.5 \%, 53.7 \%$ and $60 \%$ of women, respectively $[4,13$, $20,24]$. The next most common source of information was media and television $[4,13,20]$. Doctors were also noted as a source of information $[4,12,13,20]$. A study conducted in Jeddah found that $63 \%$ of the women taking oral contraceptive pills were doing so because of a doctor's advice [18]. Similarly, studies by Al-Turki and Farih found that doctors were common source of information than friends $[12,15]$. Table 4 below summarises the sources of information.

Table 4. Sources of Information.

\begin{tabular}{llll}
\hline \multirow{2}{*}{ Sources/ studies } & Abdel-Fattah et al. 2007 & Al Sheeha 2010 & Al-Turki 2011 \\
\cline { 2 - 4 } & $\mathbf{\%}$ & $\mathbf{\%}$ & $\mathbf{\%}$ \\
\hline Family & 67.5 & 32.9 & - \\
Friend & 57.3 & - & 24 \\
Media & 58 & 21.5 & - \\
TV & - & 26.3 & - \\
Doctor & 43.9 & 17.3 & 64 \\
Internet & - & 2 & - \\
\hline
\end{tabular}

\begin{tabular}{lllll}
\hline \multirow{2}{*}{ Sources/ studies } & Iftikhar \& Aba Al Khail 2015 & Karim et al., 2015 & Farih 2016 & Al-Shamranie al. 2016 \\
\cline { 2 - 5 } & $\mathbf{\%}$ & $\mathbf{\%}$ & $\mathbf{\%}$ & $\mathbf{\%}$ \\
\hline Family & - & 60 & - & 53.7 \\
Friend & - & 13.3 & 6 & 53.7 \\
Media & - & 20 & - & 19.3 \\
TV & - & - & - & - \\
Doctor & 63 & 6.6 & 8.8 & 17.6 \\
Internet & - & 20 & 6.6 & - \\
\hline
\end{tabular}

\subsection{Use of Contraceptive Methods:}

Fifteen studies, summarised in Table 5, explored the use of contraceptives $[4,6,8,9,10,11$ 13, 15, 17, 18, 19, 20, 21, $23,26]$. The studies have conclude that women had used contraceptives. Contraceptive use was varied by region; there is only $27 \%$ of women used contraception in the study conducted in Abha [17]. However, this study did not investigate the reasons why women did not use contraceptives. While, Al Sheeha's (2010) study noted that $55 \%$ of women had never used contraceptives [4]. There are many reasons for not using contraceptives. In Al Sheeha study emphasize that women did not use contraceptive because children are a blessing from God and the harmful effects contraceptives have on marital life [4]. Moreover, a study of Abdel-Fattah et al. noted many factors that let women not using contraceptives were newly married and need children, having a husband who refused and being concerned about side effects [13]. In addition, in Albezrah and Farih's study found that women did not use contraceptives due to religious factors, fear of side effects, lack of knowledge and rejection by husband $[10,12]$. Also, a study of Alsulaiman and his colleagues noticed that the working status of women as well as husband approval were factors that may affecting the use of contraceptive [22].

The most commonly used contraceptive in SA is the oral pill $[4,8,9,10,11,12,13,15,16,17,18,19,20,22]$. In contrast, however, a study done in Al-Khobar found that the most commonly used contraceptives were condoms, patches, withdrawal, foam, and tubal ligation, which were used by $43 \%$ of women [6]. These differences in contraceptive preference may be because Al-Khobar is considered an advanced and open city with a multicultural background.

IUDs were the second most commonly used contraceptive $[4,9,10,12,13,15,17,19,20]$. One study noted that working women preferred using the IUD as a contraceptive [17].

Studies by Abdel-Fattah et al. and Rasheed and Al-Dabal mentioned that the fertility awareness was the third most commonly preferred contraceptive method $[9,13]$. Studies by Al Sheeha, Al-Turki and Farih, however, noted that the condom was preferred over the fertility awareness $[4,12,15]$.

Other contraceptive methods such as lactational amenorrhea, withdrawal, injections, spermicidal and tubal ligation are also noted to be used by women $[6,12,13,19,20]$. 
Table 5. Use of contraceptives in women.

\begin{tabular}{|c|c|c|c|c|c|c|c|c|}
\hline \multirow[t]{2}{*}{ Methods/ Studies } & \multicolumn{2}{|c|}{ Rasheed \& Al-Dabal 2007} & \multicolumn{2}{|c|}{ Abdel-Fattah et al 2007} & \multicolumn{2}{|c|}{ Al Sheeha 2010} & Al-Turki 2011 & \multirow{2}{*}{$\begin{array}{l}\text { Al-Mansour, Sabra, \& } \\
\text { Hafez } 2012 \\
\%\end{array}$} \\
\hline & $\%$ & & $\%$ & & $\%$ & & $\%$ & \\
\hline Oral pill & 65.1 & & 44 & & 70 & & 36.6 & 28 \\
\hline IUD & 24.5 & & 29.4 & & 12 & & 19.9 & 6.7 \\
\hline Condom & 7.1 & & 2.9 & & 7.1 & & & 43 \\
\hline Fertility Awareness & 9.6 & & 5.4 & & 4 & & & 7 \\
\hline Lactational Amenorrhea & 20.6 & & & & 3.1 & & & 12.7 \\
\hline Withdrawal & 6 & & & & 3.6 & & & \\
\hline Injections & 0.9 & & 2.9 & & & & & \\
\hline Sterilisation & & & & & Few & & & \\
\hline \multirow{2}{*}{ Methods/ Studies } & Farheen 2013 & & \multicolumn{2}{|c|}{ Mahboub et al., 2015} & & Al-Shamranie al. 2016 \\
\hline & $\%$ & \multicolumn{2}{|c|}{$\begin{array}{l}\text { Albezrah, } 2015 \\
\%\end{array}$} & \multicolumn{2}{|c|}{$\%$} & \multicolumn{2}{|c|}{$\begin{array}{l}\text { Elgharabawy et al. } 2015 \\
\%\end{array}$} & $\%$ \\
\hline Oral pill & 62.9 & \multicolumn{2}{|l|}{53.8} & \multicolumn{2}{|l|}{64.9} & \multicolumn{2}{|l|}{$\frac{\%}{49.1}$} & 33.9 \\
\hline IUD & 37 & \multicolumn{2}{|l|}{34.3} & 20 & & \multicolumn{2}{|l|}{16} & 22 \\
\hline Condom & & \multicolumn{3}{|l|}{3.6} & & \multicolumn{2}{|l|}{17} & 6 \\
\hline Fertility Awareness & & & & & & & & 5.9 \\
\hline Lactational Amenorrhea & & & & & & & & 5.9 \\
\hline Withdrawal & & & & & & & & 5.9 \\
\hline Injections & & \multirow{2}{*}{\multicolumn{2}{|c|}{8.3}} & 0.4 & & & & 1.3 \\
\hline Sterilisation & & & & & & & & \\
\hline
\end{tabular}

\subsection{Contraceptive Counseling}

No study was found that investigated counseling about contraceptive methods in Saudi Arabia. In fact, all of the studies agreed that effective counseling and education were needed to improve women's knowledge and enable them to use their preferred contraceptive method properly $[4,6,9,10,15,16,17$, $22,24]$. Moreover, they promoted the need for contraceptive clinics so that women can receive better counseling $[15,19]$.

Table 6. Summary of studies in KSA.

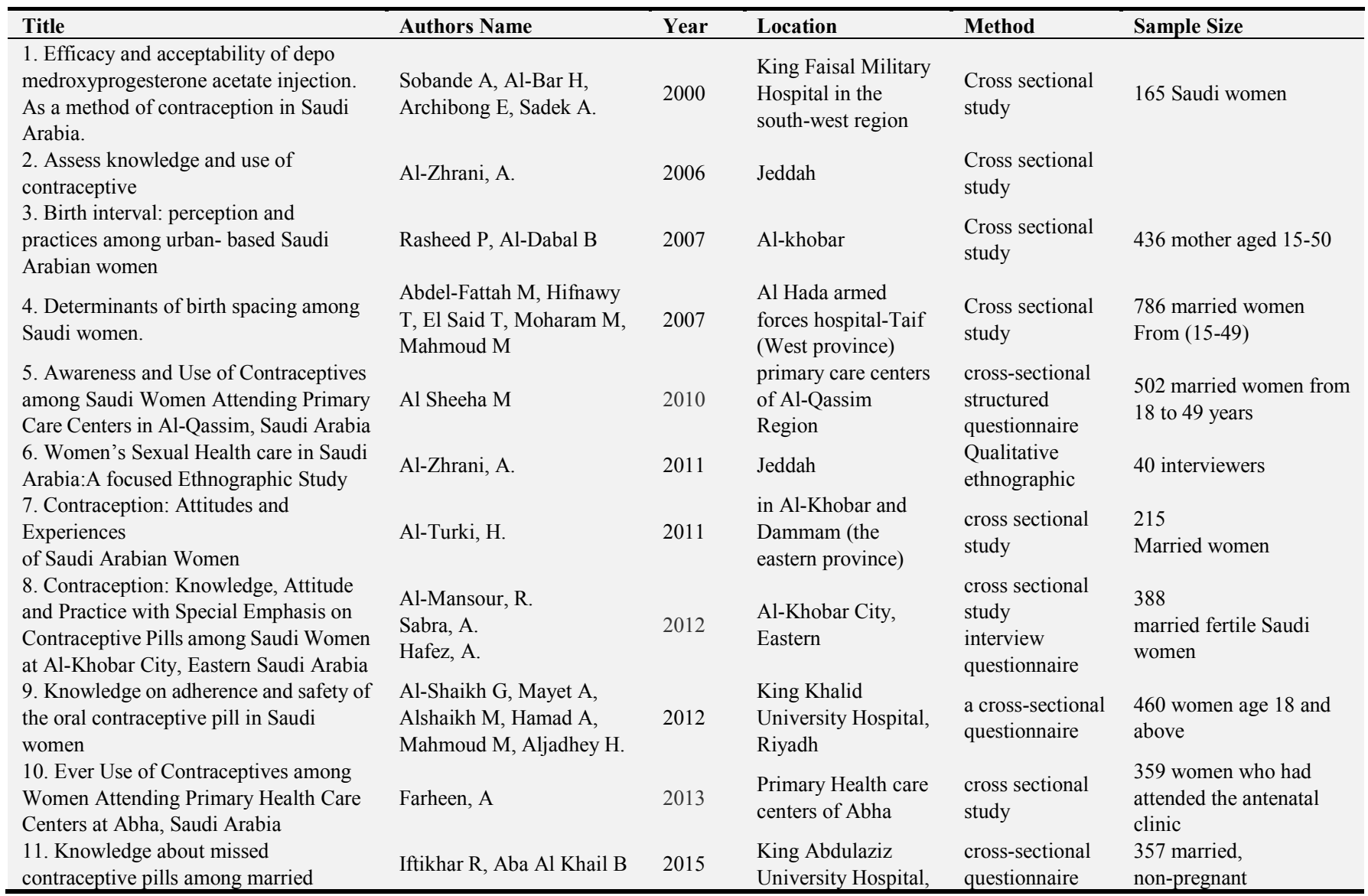




\begin{tabular}{|c|c|c|c|c|c|}
\hline Title & Authors Name & Year & Location & Method & Sample Size \\
\hline $\begin{array}{l}\text { women at King Abdulaziz University } \\
\text { Hospital }\end{array}$ & & & Jeddah & & women $>18$ years \\
\hline $\begin{array}{l}\text { 12. Awareness, Prevalence and } \\
\text { Determinants of Birth Control Methods } \\
\text { Use among Women in Saudi Arabia }\end{array}$ & $\begin{array}{l}\text { Elgharabawy, R., Ahmed, } \\
\text { A.\& Alsuhaibani, R. }\end{array}$ & 2015 & $\mathrm{Al}$-Qassim region & $\begin{array}{l}\text { cross sectional } \\
\text { study }\end{array}$ & $\begin{array}{l}300 \text { women in Saudi } \\
\text { Arabia aged } 18-49 \text { years }\end{array}$ \\
\hline $\begin{array}{l}\text { 13. Attitude towards Contraceptives Use } \\
\text { among Saudi Women }\end{array}$ & Mahboub, $\mathrm{S}$ et al. & 2015 & Riyadh city & $\begin{array}{l}\text { descriptive } \\
\text { cross sectiona }\end{array}$ & $\begin{array}{l}305 \text { married Saudi } \\
\text { females }\end{array}$ \\
\hline $\begin{array}{l}\text { 14. Use of modern family planning } \\
\text { methods among Saudi women in Taif, } \\
\text { KSA }\end{array}$ & Albezrah & 2015 & Taif & $\begin{array}{l}\text { cross sectional } \\
\text { study }\end{array}$ & $\begin{array}{l}250 \text { women in obstetrics } \\
\text { outpatient clinics }\end{array}$ \\
\hline $\begin{array}{l}\text { 15. Knowledge, Attitudes and Practices } \\
\text { towards Family Planning among Saudi } \\
\text { Female Teachers in Al-Madinah } \\
\text { Al-Munawarah City, Saudi Arabia }\end{array}$ & Alharbi, M. et al. & 2016 & $\begin{array}{l}\text { Al-Madinah } \\
\text { Al-Munawarah }\end{array}$ & $\begin{array}{l}\text { cross sectional } \\
\text { study }\end{array}$ & $\begin{array}{l}300 \text { Saudi female teacher } \\
\text { in governmental schools }\end{array}$ \\
\hline $\begin{array}{l}\text { 16. Dynamics of contraceptive use: A } \\
\text { study of King Saud University women } \\
\text { staff, Riyadh }\end{array}$ & Khraif, R. et al. & 2016 & Riyadh city & $\begin{array}{l}\text { descriptive } \\
\text { cross sectiona }\end{array}$ & $\begin{array}{l}354 \text { married women in } \\
\text { King Saud University }\end{array}$ \\
\hline $\begin{array}{l}\text { 17. Factors affecting attitudes of Saudi } \\
\text { women towards contraceptive use }\end{array}$ & Mahboub, S & 2015 & Riyadh & $\begin{array}{l}\text { descriptive } \\
\text { cross sectional } \\
\text { study }\end{array}$ & 305 ever married females \\
\hline $\begin{array}{l}\text { 18. Emergency contraception: } \\
\text { Awareness, attitudes and barriers of } \\
\text { Saudi Arabian Women }\end{array}$ & Karim, S. et al. & 2015 & Riyadh city & $\begin{array}{l}\text { descriptive } \\
\text { cross sectional }\end{array}$ & $\begin{array}{l}242 \text { women Women in } \\
\text { the reproductive age }\end{array}$ \\
\hline $\begin{array}{l}\text { 19. Knowledge, Attitude and Practice of } \\
\text { Saudi Women towards The Use of Oral } \\
\text { Contraceptive Pills }\end{array}$ & $\begin{array}{l}\text { Al-Shamrani, A., Tayeb, } \\
\text { S., Alsaggaf, A. \&Alafif, } \\
\text { M. }\end{array}$ & 2016 & Jeddah & $\begin{array}{l}\text { cross sectional } \\
\text { study }\end{array}$ & $\begin{array}{l}713 \\
\text { Saudi women }\end{array}$ \\
\hline $\begin{array}{l}\text { 20. An exploratory study of sexual and } \\
\text { reproductive health knowledge, } \\
\text { information-seeking behaviour and } \\
\text { attitudes among Saudi women: A } \\
\text { questionnaire survey of university } \\
\text { students }\end{array}$ & Farih, M & 2016 & Riyadh city & $\begin{array}{l}\text { descriptive } \\
\text { cross sectional }\end{array}$ & $\begin{array}{l}365 \text { female study from } 4 \\
\text { universities }\end{array}$ \\
\hline $\begin{array}{l}\text { 21. Knowledge of combined oral } \\
\text { contraceptives among young females in } \\
\text { Riyadh }\end{array}$ & $\begin{array}{l}\text { Alsulaiman, } \mathrm{T} \text {. } \\
\text { et al. }\end{array}$ & 2017 & Riyadh & $\begin{array}{l}\text { cross sectional } \\
\text { study }\end{array}$ & $\begin{array}{l}426 \text { young females aged } \\
18-40\end{array}$ \\
\hline
\end{tabular}

Table 6. Continued.

\begin{tabular}{|c|c|c|c|}
\hline Title & Result & Conclusion & Recommendation \\
\hline $\begin{array}{l}\text { 1. Efficacy and acceptability } \\
\text { of depo medroxyprogesterone } \\
\text { acetate injection. As a method } \\
\text { of contraception in Saudi } \\
\text { Arabia. }\end{array}$ & $\begin{array}{l}80 \% \text { of the women knew about depoprovera } \\
30 \% \text { had heard about the side effects of the } \\
\text { contraceptive method. } \\
4 \% \text { of all women thought other contraceptive } \\
\text { method as a result of unacceptable side effects. }\end{array}$ & $\begin{array}{l}\text { Depo-provera is a very effective } \\
\text { form of contraception. }\end{array}$ & $\begin{array}{l}\text { side effects are treatable } \\
\text { medically together with the } \\
\text { pretreatment counseling }\end{array}$ \\
\hline $\begin{array}{l}\text { 2. Assess knowledge and use } \\
\text { of contraceptive }\end{array}$ & $\begin{array}{l}\text { majority of women were aware of advantage and } \\
\text { disadvantages of COC, IUD, calendar and } \\
\text { withdrawal the nurse have limited role in } \\
\text { contraceptive and family planning education }\end{array}$ & $\begin{array}{l}\text { women had limited knowledge } \\
\text { about contraceptives }\end{array}$ & $\begin{array}{l}\text { The message of optimum birth } \\
\text { interval has to reach the people, } \\
\text { and the responsibility for this } \\
\text { rests with those involved in the } \\
\text { health care of the community. }\end{array}$ \\
\hline $\begin{array}{l}\text { 3. Birth interval perception } \\
\text { and practices among urban- } \\
\text { based Saudi Arabian women }\end{array}$ & $\begin{array}{l}36.5 \% \text { of women noted that } 2 \text { years was the ideal } \\
\text { birth interval. } \\
\text { Oral pill used by } 65 \% \text { women } \\
\text { Followed IUD used by } 24.5 \% \\
\text { The Breast feeding used by } 20.6 \% \text { as } \\
\text { contraceptive method. } \\
\text { The rhythm, withdrawal, condom and injection } \\
\text { used by } 9.6 \%, 6 \%, 7.1 \% \text { and } 0.9 \% \text { respectively } \\
\text { pill was the most reported method }(44.1 \%)\end{array}$ & $\begin{array}{l}\text { The women had lake of } \\
\text { knowledge regard the birth } \\
\text { interval. } \\
\text { The oral contraceptive was the } \\
\text { most method used. }\end{array}$ & $\begin{array}{l}\text { The message of optimum birth } \\
\text { interval has to reach the people, } \\
\text { and the responsibility for this } \\
\text { rests with those involved in the } \\
\text { health care of the community. }\end{array}$ \\
\hline $\begin{array}{l}\text { 4. Determinants of birth } \\
\text { spacing among Saudi women. }\end{array}$ & $\begin{array}{l}\text { Intrauterine devices used by }(29.4 \%) \\
\text { safe period, condoms, injectables and others were } \\
\text { also mentioned } 5.4 \%, 2.9 \%, 2.9 \% \text { and } 3.2 \% \\
\text { respectively }\end{array}$ & $\begin{array}{l}\text { certain factors were significant } \\
\text { predictors of interbirth spacing for } \\
\text { the Saudi women }\end{array}$ & further studies were needed \\
\hline $\begin{array}{l}\text { 5. Awareness and Use of } \\
\text { Contraceptives among Saudi } \\
\text { Women Attending Primary } \\
\text { Care Centers in Al-Qassim, } \\
\text { Saudi Arabia }\end{array}$ & $\begin{array}{l}50 \% \text { had low level of knowledge regarding the } \\
\text { contraceptive methods } \\
\text { The main source of women's knowledge was the } \\
\text { family members ( } 32.9 \% \text { ) } \\
\text { oral pills were the most commonly used method, }\end{array}$ & $\begin{array}{l}\text { the women have low level of } \\
\text { knowledge in contraceptive }\end{array}$ & $\begin{array}{l}\text { increase awareness and } \\
\text { motivation for proper } \\
\text { contraceptive use }\end{array}$ \\
\hline
\end{tabular}




\begin{tabular}{|c|c|c|}
\hline Title & Result & Conclusion \\
\hline $\begin{array}{l}\text { 6. Women's Sexual Health } \\
\text { care in Saudi Arabia:A } \\
\text { focused Ethnographic Study }\end{array}$ & $\begin{array}{l}\text { with } 70.2 \% \\
\text { IUD used by } 12.0 \% \\
\text { rhythm, withdrawal and breast feeding used by } \\
4.0 \%, 3.6 \% \text { and } 3.1 \% \text {, respectively } \\
\text { Contraceptive was used by women. } \\
\text { Husband played an important role in decision. } \\
\text { Majority of women gain information from frinds } \\
\text { and relatives. }\end{array}$ & $\begin{array}{l}\text { Contraceptives were used to space } \\
\text { pregnancies } \\
\text { husbands have great influence on } \\
\text { the decision to use contraceptives }\end{array}$ \\
\hline $\begin{array}{l}\text { 7. Contraception: Attitudes } \\
\text { and Experiences } \\
\text { of Saudi Arabian Women }\end{array}$ & $\begin{array}{l}(36.6 \%) \text { of women were using oral contraception } \\
\text { pills (OCP). } \\
19.9 \% \text { were used intra uterine device (IUD). }\end{array}$ & $\begin{array}{l}\text { The majority of Saudi women } \\
\text { used contraceptive methods } \\
\text { without medical advice. }\end{array}$ \\
\hline $\begin{array}{l}\text { 8. Contraception: } \\
\text { Knowledge, Attitude and } \\
\text { Practice with Special } \\
\text { Emphasis on Contraceptive } \\
\text { Pills among Saudi Women at } \\
\text { Al-Khobar City, Eastern } \\
\text { Saudi Arabia }\end{array}$ & $\begin{array}{l}28.7 \% \text { used OCC } \\
6.7 \% \text { used IUD } \\
43.3 \% \text { used barrier. }\end{array}$ & $\begin{array}{l}\text { The majority } \\
\text { of Saudi women had poor } \\
\text { knowledge, practice and negative } \\
\text { attitudes towards OCP }\end{array}$ \\
\hline $\begin{array}{l}\text { 9. Knowledge on adherence } \\
\text { and safety of the oral } \\
\text { contraceptive pill in Saudi } \\
\text { women }\end{array}$ & $\begin{array}{l}79 \% \text { of women know take extra pill if they forgot } \\
\text { to take it before } 12 \mathrm{hr} \text {. } \\
6.5 \% \text { know take extra pill and protection if the } \\
\text { forget to take if more than } 12 \mathrm{hr} \text {. } \\
9.8 \% \text { know take extra pill and protection if they } \\
\text { vomit or have diarrhea. }\end{array}$ & $\begin{array}{l}\text { Most Saudi women taking OCPs } \\
\text { have limited knowledge of its } \\
\text { correct use regarding missing } \\
\text { pills, vomiting and diarrhea, and } \\
\text { poor awareness of the effects of } \\
\text { smoking while using OCPs. }\end{array}$ \\
\hline
\end{tabular}

\section{Ever Use of}

Contraceptives among

Women Attending Primary

Health Care Centers at Abha,

Saudi Arabia

11. Knowledge about missed contraceptive pills among married women at King Abdulaziz University Hospital

12. Awareness, Prevalence and Determinants of Birth Control Methods Use among Women in Saudi Arabia

13. Attitude towards Contraceptives Use among Saudi Women

14. Use of modern family planning methods among Saudi women in Taif, KSA

15. Knowledge, Attitudes and Practices towards Family Planning among Saudi Female Teachers in Al-Madinah Al-Munawarah City, Saudi Arabia

16. Dynamics of contraceptive use: A study of King Saud University women
Oral pill was the most commonly used $62.9 \%$ $37 \%$ used IUD

$60 \%$ responded that OCPs were one of the most reliable methods.

$20 \%$ of women know what to do in case of vomit within $2 \mathrm{hr}$.

$64 \%$ of women know if forgot the pill

$63 \%$ have in adequate knowledge about oral contraceptive pill.

$18 \%$ of women did not have any idea about birth control

$82 \%$ of women used contraceptives.

Most common used were COC, condom, IUD and patches.

$13.9 \%$ of women were not used contraception

$86.6 \%$ of women have ever used contraception most commonly used method were contraceptive pills by $64.9 \%$ of women

$20 \%$ of women used IUD

$67.7 \%$ of women was using contraception

The most common contraceptive used was COC (53.8\%), IUD and injectable contraception respectively (34.3\% and $8.3 \%)$.

Religious believes was the most given reason for not using any method of contraception reported by $53.8 \%$

one third or less of participants answered correctly related to contraception

$63.7 \%$ of women need health education regards contraceptives

$46.6 \%$ of preferred health centers as source of information

$76.3 \%$ of women reported that use of contraceptives

$53.4 \%$ use some method

\section{Recommendation}

empowering women, enhancing health care provider function and role

The society lacks contraception clinics were women can get better counseling with culturally competent counselors

Effective counseling and education are needed for negatively disposed toward OCP use.

Low use of contraceptives found

Women had poor knowledge about OCP use

Proper education and counseling

Knowledge of different contraceptive methods and their benefits on women's and children's health needs to be emphasized in the community

primary health care providers, including physicians, nurses, and pharmacists, have a responsibility to counsel patients so that they understand OCP instructions.

Future public health initiatives in SA should focus on raising awareness of contraception and increasing access to a variety of contraceptive methods

Attitude of females towards contraception was affected by working status husband approval was a factor to improve female attitude towards contraceptives

the prevalence of contraception use among Saudi women of reproductive age was $67.7 \%$

limited knowledge of contraceptive methods, high intention to use contraceptives, and average use of contraceptives

conduct health education programs regarding contraceptives; their side effects and safety in all primary care clinics in Saudi Arabia

continuous health education in the field of family planning is necessary

Education the community on importance of contraception and establish awareness campaigns to raise awareness about various contraceptive methods and how to use.

There are many variables that affect contraceptive use such as age, number of marriages, age of
There are variable need to programs to create a change in manipulate through policies and 


\begin{tabular}{|c|c|c|c|}
\hline Title & Result & Conclusion & Recommendation \\
\hline staff, Riyadh & & $\begin{array}{l}\text { the husband, type of family, type } \\
\text { of job, and income. }\end{array}$ & contraception. \\
\hline $\begin{array}{l}\text { 17. Factors affecting attitudes } \\
\text { of Saudi women towards } \\
\text { contraceptive use }\end{array}$ & $\begin{array}{l}86.6 \% \text { of women used contraception most } \\
\text { commonly used method were contraceptive pills } \\
\text { by } 64.9 \% \text { of women }\end{array}$ & $\begin{array}{l}\text { Working status and husband } \\
\text { approval were a significant factor } \\
\text { improving female attitude towards } \\
\text { contraceptives. }\end{array}$ & $\begin{array}{l}\text { Sustained efforts should be } \\
\text { done to increase awareness } \\
\text { regard contraceptives }\end{array}$ \\
\hline $\begin{array}{l}\text { 18. Emergency } \\
\text { contraception: Awareness, } \\
\text { attitudes and barriers of Saudi } \\
\text { Arabian Women }\end{array}$ & $\begin{array}{l}93.8 \% \text { not have knowledge of EC } 13.3 \% \text { had used } \\
\text { emergency contraceptive pills previously } \\
\text { Majority }(73.3 \%) \text { had negative attitude toward EC }\end{array}$ & $\begin{array}{l}\text { Knowledge of emergency } \\
\text { contraception is very low among } \\
\text { women of Saudi Arabia }\end{array}$ & $\begin{array}{l}\text { Designing programs for to } \\
\text { educate women about EC }\end{array}$ \\
\hline $\begin{array}{l}\text { 19. Knowledge, Attitude and } \\
\text { Practice of Saudi Women } \\
\text { towards The Use of Oral } \\
\text { Contraceptive Pills }\end{array}$ & $\begin{array}{l}79 \% \text { have used at least on method. Most } \\
\text { contraceptives used were COC by } 34 \% \text {, IUD } \\
22 \% \text {, natural methods } 5.9 \% \text { and condom } 6 \% \text {. }\end{array}$ & $\begin{array}{l}\text { High knowledge level regards oral } \\
\text { pill }\end{array}$ & $\begin{array}{l}\text { More educational campaigns } \\
\text { need to be organized by the } \\
\text { interested ministries to educate } \\
\text { women better about various } \\
\text { means of contraceptive use. }\end{array}$ \\
\hline $\begin{array}{l}\text { 20. An exploratory study of } \\
\text { sexual and reproductive } \\
\text { health knowledge, } \\
\text { information-seeking } \\
\text { behaviour and attitudes } \\
\text { among Saudi women: A } \\
\text { questionnaire survey of } \\
\text { university students }\end{array}$ & $\begin{array}{l}84.1 \% \text { had a poor general knowledge where single } \\
\text { students have low knowledge more than married. } \\
10 \% \text { of women used contraceptive } \\
\text { Reasons for not use contraceptive were religion, } \\
\text { fear of side effects, and lack of knowledge and } \\
\text { refusal of husband. }\end{array}$ & $\begin{array}{l}\text { limited understanding of the } \\
\text { sexual and reproductive health } \\
\text { needs and problems for the } \\
\text { participant }\end{array}$ & $\begin{array}{l}\text { Designing programs for } \\
\text { universities and schools within } \\
\text { Saudi and Islamic culture for } \\
\text { sexual and reproductive health. }\end{array}$ \\
\hline $\begin{array}{l}\text { 21. Knowledge of combined } \\
\text { oral contraceptives among } \\
\text { young females in Riyadh }\end{array}$ & $\begin{array}{l}60 \% \text { were current or previous users of } \\
\text { contraceptive pills } \\
\text { mean scores were low, indicating poor level of } \\
\text { knowledge }\end{array}$ & $\begin{array}{l}\text { poor level of knowledge on COCs } \\
\text { among young females in Riyadh. }\end{array}$ & $\begin{array}{l}\text { Increase the awareness level by } \\
\text { health education campaigns as } \\
\text { well as family planning clinics }\end{array}$ \\
\hline
\end{tabular}

\section{Discussion}

Several Saudi studies have reported that most women have heard and used contraceptives [4, 6, 8, 15, 16, 18, 27]. Thus, these studies concluded that the concept of contraception is known in Saudi society. Women's increased awareness is likely due to the change that has happen in Saudi lifestyle which encourages women to get better education that led to empower them in seeking information through reading and Internet searching. In recent years the Saudi community has changed rapidly, particularly regarding women's education and employment; many consider these factors to be important in determining women's beliefs, attitudes and practices towards contraceptives [20]. Likewise, a study conducted in Qatar revealed that knowledge of family planning increased significantly as education levels increased [28]. In addition to women's education, mass media and TV programs likely play a role in raising awareness about family planning. Many channels and TV programs depict medical topics that discuss women's and family issues.

Other studies conducted in KSA also found that the most popularly known contraceptive was the oral contraceptive pill; awareness of IUD, fertility awareness (schedule), lactational amenorrhea, withdrawal, male condom, injection and fallopian tube ligation were also reported $[4,8,11]$. A study in Qatar reported that women mostly knew about oral contraceptive pills $(90.0 \%)$, followed by IUDs (89.1\%) [28].

Based on previous studies, it seems that the most popularly known contraceptives in the Gulf area are oral contraceptive pill and IUD. Their popularity may be because women are looking for contraceptives which provide highly effective protection against pregnancy. Alternatively, doctors may advise new mothers to use contraceptives which have less serious sides effect, are readily available and are easy to use. Contraceptive methods such as diaphragm and vaginal rings are less to be known by women and to be use. Therefore, it was surprising; in Farih's study to found that $43 \%$ of women know about diaphragm [12]. When looking to the characteristics of the Farih's study was found that his study carried on the universities and participant were educated women [12]. This result emphasised that educations has positive influence on contraceptive awareness and use even in a very religious and conservative countries.

Al-Shamrani, Tayeb, Alsaggaf, and Alafif's study reported that the main sources of women's contraceptive knowledge $(53.7 \%)$ were friends and family members [20]. A study by Abdel-Fattah et al. conducted in Taif found that parents and family were the primary sources of knowledge [13]. It seems that family and friends are the most common source of information due to Saudi cultural norms. In Saudi society, women stay in the family home for the first forty days postpartum, a period called (Nefass). It is common during the (Nefass) period for friends and relatives to visit postpartum women and shared their experiences about the contraceptives they have used or heard about. Thus, friends and family are the main sources of information about contraception. Another reason most information comes from friends and family may be the lack of school curriculum to educate women about contraceptives and reproductive health. Even if the level of education in SA improves, there is no reproductive health education curriculum in schools or universities [12]. None of the participants in the reviewed studies have reported receiving information about contraceptives from school curriculum. This finding highlights the need to develop social 
accepted school curriculum that provides reproductive health information to students [29].

Two studies found that nurses have very limited roles in contraceptive and family planning education [12, 14]. It is disappointing that none of the women mentioned receiving contraceptive education or information by nurses. Many factors may hinder nurses from administering contraceptive counseling. Some nurses working in SA are non-Arabic speakers therefore will be difficult to communicate or provide advice. Other factors may be over lode on nurses due to of the shortage of staff and it may be also due to the restrictions of the hospital policy which allocate contraception education to the gynaecology doctors. This reasons are supported by a study conducted by Harrabi, Al Ghamdi and Xilavi [30]. They reported that nurses believed shortness of time $(68.8 \%)$, lack of common language and culture to communicate with the patient $(91.6 \%)$ and lack of patients' motivation to learn $(85.7 \%)$ were the most important causes of the insufficiency of patient education about contraceptives [30].

\section{Conclusion}

The contraceptives in Saudi women were well known. the most popularly contraceptive were oral contraceptive pill, IUD, fertility awareness (schedule), lactational amenorrhea, withdrawal, male condom, injection and fallopian tube ligation were also reported. The main source that women gain the information regards contraceptive was family members and friends. Also, nurses have very limited roles in contraceptive and family planning education. These finding highlights the need to reproductive health education should be provided by health care provider and nurses to the community.

\section{References}

[1] World Health Organization. (2016). Family planning/Contraception. Retrieved December 21, 2016.

[2] United Nations, Department of Economic and Social Affairs, Population Division (2015). Trends in Contraceptive Use Worldwide 2015.

[3] General Authority for Statistics. (2016). Demography Survey. Retrieved December 24, 2016, from

http://www.stats.gov.sa/sites/default/files/en-demographic-res earch-2016_2.pdf.

[4] Al-Sheeha, M. (2010). Awareness and use of contraceptives among Saudi women attending primary care centers in Al-Qassim, Saudi Arabia. International Journal of Health Sciences, 4 (1), 11-20. Retrieved from http://search.proquest.com/docview/1399515911 ?accountid=1 42908.

[5] Dash, M. (2011). Effectiveness of video-assisted teaching module on contraceptive methods among the couples-Pondicherry. (PhD thesis), Sri Ramachandra University, India.

[6] Al-Mansour, R., Sabra, A., \& Hafez, A. (2012). Contraception: Knowledge, attitude, and practice with special emphasis on contraceptive pills among Saudi Women at Al-Khobar city. Eastern Saudi Arabia. The Egyptian Journal of Community Medicine, 30 (2), 1-13.

[7] Anjum, S., Durgawale, P. M., \& Shinde, M. (2014). Knowledge of contraceptives methods and appraisal of health education among married women. International Journal of Science and Research, 3 (3), 584-590.

[8] Al-Zahrani, A. (2006). Knowledge, attitudes and practices of contraception among women in Saudi Arabia and their views on the provision of contraception education by nurses in family planning clinics. (Unpublished Master Thesis). King's College, London.

[9] Rasheed, P., \& Al-Dabal, B. (2007). Birth interval: Perceptions and practices among urban-based Saudi Arabian women. Eastern Mediterranean Health Journal, 13 (4), 881-892.

[10] Albezrah, N. (2015). Use of modern family planning methods among Saudi women in Taif, KSA. International Journal of Reproduction, Contraception, Obstetrics and Gynecology, 4 (4), 990-994. doi: 10.18203/2320-1770.ijrog20150412.

[11] Elgharabawy, R., Ahmed, A., \& Alsuhaibani, R. (2015). Awareness, prevalence and determinants of birth control methods use among women in Saudi Arabia. International Archives of Medicine, 8 (245), 1-11. doi: 10.3823/1844.

[12] Farih, M. (2016). An exploratory study of sexual and reproductive health knowledge, information-seeking behaviour and attitudes among Saudi women: A questionnaire survey of university students (PhD thesis), Queen Mary University of London, London. Retrieved from http://qmro.qmul.ac.uk/xmlui/handle/123456789/12825.

[13] Abdel-Fattah, M., Hifnawy, T., El Said, T., Moharam, M., \& Mahmoud, M. (2007). Determinant of birth spacing among Saudi women. Journal of Family \& Community Medicine, 14 (3), 103-111.

[14] Al-Zahrani, A. (2010). Women's sexual health care in Saudi Arabia: A focused ethnographic study (PhD thesis). University of Sheffield. Retrieved from

http://etheses.whiterose.ac.uk/1436/.

[15] Al-Turki, H. (2011). Contraception: Attitudes and experiences of Saudi Arabian women. Health Care for Women International, 32 (2), 134-139. Available at: 10.1080/07399332.2010.536280.

[16] Al-Shaikh, G., Mayet, A., Alshaikh, M., Hamad, A., Mahmoud, M., \& Aljadhey, H. (2012). Knowledge on adherence and safety of the oral contraceptive pill in Saudi Women. Saudi Medical Journal, 33 (6), 665-669.

[17] Farheen, A. (2013). Ever use of contraceptives among women attending primary health care centers at Abha, Saudi Arabia. International Journal of Current Research and Review, 5 (10), 26. Retrieved from http://search.proquest.com/docview/1399515911?accountid=1 42908.

[18] Iftikhar, R., \& Aba Al Khail, B. (2015). Knowledge about missed contraceptive pills among married women at King Abdulaziz University Hospital. Patient Preference and Adherence, 9, 401-411.

[19] Mahboub, S. (2015). Factors affecting attitudes of Saudi women toward contraceptive use. Retrieved from http://fac.ksu.edu.sa/sababdelkader/publication/193521. 
[20] Al-Shamrani, A., Tayeb, S., Alsaggaf, A., \& Alafif, M. (2016). Knowledge, attitude and practice of Saudi women towards the use of oral contraceptive pills. Hamdan Medical Journal, 8 (4). doi: $10.7707 / \mathrm{hmj} .595$.

[21] Khraif, R., Abdul Salam, A., Al-Mutairi, A., Elsegaey, I. \& Ajumah, A. (2016). Dynamics of contraceptive use: A study of King Saud University women's staff, Riyadh. Middle East Fertility Society Journal, 1-9. doi: 10.1016/j.mefs.2016.09.006.

[22] Alsulaiman, T., Alamer, M., Alrajeh, G., Khojah, Q., Alrumaihi, S.,\& Almutairi, O. (2017). Knowledge of combined oral contraceptives among young females in Riyadh. International Journal of Medical Science and Public Health, 6 (4), 752-756. DOI: 10.5455/ijmsph.2017.1266406122016.

[23] Sobande, A., Al-Bar, H. Archibong, E., \& Sadek, A. (2000). Efficacy and acceptability of depomedroxyprogesterone acetate injection as a method of contraception in Saudi Arabia. Saudi Medical Journal, 21 (4), 348-351.

[24] Karim, S., Irfan, F., Al-Rowais, N., Al-Zahrani, B., Qureshi, R., \& Al-Qadrah, B. (2015). Emergency contraception: Awareness, attitudes and barriers of Saudi Arabian Women. Pakistan Journal of Medical Sciences, 31 (6), 1500-1505. doi: http://dx.doi.org/10.12669/pjms.316.8127.

[25] Hassan, S. (1990). Knowledge of Saudi mothers in relation to selected aspects of maternal and infant health (Unpublished Master's dissertation). King Saud University, Saudi Arabia.

[26] Alharbi, M., Alharbi, M., Alnazzawi, A., Albasri, R., Al Towairqi, M. Abdallah, A. (2016). Knowledge, attitudes and practices towards family planning among Saudi female teachers in Al-Madinah Al-Munawarah City, Saudi Arabia. International Journal of Academic Scientific Research, 4 (1), 82-92.

[27] Nath, J., \& Islam, F. (2014). A study on the knowledge, attitude and practice about contraception in postpartum women of North India. International Journal of Science and Research, 4 (12), 465-468.

[28] Arbab, A., Bener, A., \& Abdulmalik, M. (2011). Prevalence, awareness and determinants of contraceptive use in Qatari women. Eastern Mediterranean Health Journal, 17 (1), 11-18.

[29] Tork, H. \& Al Hosis, K. (2015). Effects of reproductive health education on knowledge and attitudes among female adolescents in Saudi Arabia. The Journal of Nursing Research, 23 (3), 236-242. doi: 10.1097/jnr.0000000000000105.

[30] Harrabi, I., Al Ghamdi, S., \& Xilavi, A. (2016). Nurses' and doctors' attitudes to patient education barriers in Najran Armed Forces Hospital, KSA. Ibnosina Journal of Medicine and Biomedical Sciences, 8 (1), 19-22. Available at: http://journals.sfu.ca/ijmbs/index.php/ijmbs/article/view/586. 